\title{
ANFIS DENGAN MEMBERSHIP FUNCTION UNTUK PREDIKSI CURAH HUJAN PADA DATA RENTET WAKTU MULTIVARIATE
}

\author{
Lilis Anggraini \\ Fakultas Teknologi Informasi \\ Universitas Islam Kalimantan Muhammad Arsyad Al Banjari Banjarmasin \\ Email : lilis.anggraini@gmail.com
}

\begin{abstract}
ABSTRAK
Masyarakat di sektor pertanian dan kelautan khususnya sangat memerlukan informasi tingkat curah hujan yang akan terjadi karena sangat berpengaruh kepada proses masa tanam hingga hasil produksi yang akan didapat dan juga berpengaruh terhadap nelayan yang ingin melaut. Sementara prakiraan cuaca yang diterbitkan BMKG ke masyarakat masih berkisar pada prediksi musim tidak konsenterasi pada tingkat curah hujan, BMKG memiliki data tingkat curah hujan namun belum dioptimalkan sebagai informasi prediksi yang diharapkan.

Oleh karena itu diperlukan metode yang akurat sehinga dapat memberikan nilai akurasi yang diharapkan dan dapat memberikan kontribusi dalam bidang pertanian, kelautan, cepat tanggap darurat cuaca buruk dan tranportasi udara. Karena data curah hujan termasuk data rentet waktu, sehingga dapat dianalisa dan diprediksi. Pada penelitian ini akan dilakukan prediksi dengan pendekatan statistik dan softcomputing menggunakan Adaptive Neuro Fuzzy Inference System (ANFIS).
\end{abstract}

Kata Kunci : Curah hujan, ANFIS, Membership Function.

\section{PENDAHULUAN}

Prediksi yang dikeluarkan Stasiun Meteorologi Stagen Kotabaru selama ini sangat bermanfaat bagi sektor pertanian, perkebunan, kelautan dan prediksi tanggap darurat cuaca buruk. [1]

Pada kenyataannya prediksi yang di keluarkan Stasiun Meteorologi Stagen Kotabaru seharusnya tidak hanya pada prediksi musim saja tetapi prediksi rentet waktu curah hujan sangat bermanfaat bagi pelaksana di lapangan seperti sektor pertanian, perkebunan, kelautan dan tanggap darurat terhadap cuaca buruk bagi nelayan.

Data curah hujan dilakuan pencatatan secara harian oleh BMKG, dan selain data curah hujan juga ada data-data lain seperti data kelembaban, suhu, kecepatan angin dan penyinaran matahari, tetapi yang dimanfaatkan sebagai laporan digunakan data rata-rata bulanan.

Selama tiga dakade terakhir, sudah mulai berkembangnya teknik-teknik pendekatan dalam penyelesaian masalah yang kemudian dikenal dengan istilah soft computing. Soft computing ialah suatu model pendekatan dalam melakukan komputasi dengan meniru akal manusia dan memiliki kemampuan untuk menalar dan belajar pada lingkungan yang penuh dengan ketidaktepatan dan ketidakpastian (Jang, 1997). Bagian utama pembentuk soft computing adalah sistem fuzzy, algoritma evolusioner, jaringan syaraf dan penalaran dengan probabilitas. Adakalanya bagian-bagian utama soft computing saling dipadukan (hibrid) untuk mendapatkan algoritma yang lebih sempurna. Salah satunya adalah 
perpaduan antara jaringan syaraf tiruan dan sistem fuzzy yang dikenal sebagai sistem neuro-fuzzy.

Dengan demikian semestinya data curah hujan termasuk data rentet waktu, sehingga data dapat dianalisa dan diprediksi dengan pendekatan statistik dan atau softcomputing menggunakan Adaptive Neuro Fuzzy Inference System. [2]

Penelitian terkait tentang curah hujan pada rentet waktu banyak dilakukan oleh beberapa peneliti dengan menggunakan algoritma yang berbeda dan parameter yang berbeda.

Menerapkan dengan data yang digunakan adalah data curah hujan harian yang dibagi ke dalam 3 kelompok (in-sample I, in-sample II, out-sample). In-sample I digunakan sebagai data pelatihan untuk model tunggal ARIMA, ANFIS, dan Wavelet. Sesudah diuji diperolehlah MAE-nya secara beruntun yakni 10,55 ; 7,81; dan 6,35 yang berarti Wavelet dan ANFIS memiliki keakuratan yang lebih baik dari pada ARIMA. Selanjutnya hasil peramalan Wavelet dan ANFIS dijadikan input pada ANFIS Optimal. In-sample II digunakan sebagai data pelatihan untuk model Wavelet, ANFIS, dan ANFIS Optimal. MAE yang diperoleh masingmasingnya adalah 11,$06 ; 8,36$; dan 8,82 sedangkan untuk nilai error maksimalnya adalah 300,$17 ; 233,18$; dan 178,50. Dari hasil penelitian tersebut dapat dilihat bahwa ANFIS Optimal dapat menurunkan nilai error secara signifikan dibandingkan metode lainnya. Fithriah Musadat, Zahir Zainuddin, Merna Baharuddin [3]

Suhartono, Ria Faulina, Dwi Ayu Lusia, Bambang W. Otok, Sutikno, Heri Kuswanto [4] mengusulkan sebuah metode ensemble berdasarkan ANFIS (Adaptive Neuro Fuzzy Inference System) dan ARIMA (Autoregressive Integrated Moving Average) untuk peramalan Data curah hujan bulanan di wilayah tertentu di Indonesia, yaitu Pujon dan daerah Wagir. Metode averaging dilaksanakan untuk menemukan perkiraan ensemble dari ANFIS dan ARIMA model. Di dalam studi, Gaussian, Gbell, dan fungsi Segitiga digunakan sebagai fungsi keanggotaan di ANFIS. Akurasi perkiraan adalah dibandingkan dengan individu terbaik ARIMA dan ANFIS. Berdasarkan akar berarti kesalahan persegi (RMSE) di dataset pengujian, Hasil penelitian menunjukkan bahwa metode ANFIS individu menghasilkan perkiraan pada data bulanan curah hujan Pujon lebih akurat sedangkan model ARIMA menghasilkan perkiraan data curah hujan bulanan yang baik Wagir.

Jadi dapat disimpulkan bahwa Adaptive Neural-Fuzzy Inference System (ANFIS) telah dikenal dan dipakai luas sebagai algoritma prediksi data rentet waktu. Karena itu penelitian ini akan menggunakan Adaptive Neural-Fuzzy Inference System (ANFIS) sebagai pendekatan untuk menganalisis akurasi dengan beberapa membership function dalam mendapatkan hasil prediksi rentet waktu curah hujan yang benar.

\section{RUMUSAN MASALAH}

Berdasarkan identifikasi masalah diatas maka rumusan masalah pada penelitian ini adalah "Bagaimana menganalisis Akurasi Algoritma Adaptive Neuro Fuzzy Inference System (ANFIS) Untuk Memprediksi Curah Hujan Dengan Analisa Membership Function Pada Data Multivariate Time Series".

\section{TUJUAN PENELITIAN}

Tujuan dari penelitian ini memudahkan proses penarikan kesimpulan hasil akurasi prediksi curah hujan dengan metode Adaptive Neuro Fuzzy Inference System (ANFIS) dengan analisa membership function.

\section{TARGET LUARAN DAN MANFAAT} PENELITIAN 
Target luaran dalam pembuatan penelitian ini adalah diharapkan dapat memberikan kontribusi dalam bidang pertanian, perkebunan dan kelautan dalam proses masa tanam hingga hasil produksi yang akan didapat dan juga berpengaruh terhadap nelayan yang ingin melaut.

Manfaat dari penelitian ini adalah hasil dari penelitian dapat digunakan BMKG dalam mengelola data curah hujan yang kinerjanya akurat sebagai alat memprediksi curah hujan dengan menggunakan metode algoritma sehingga dikedepannya dapat merencanakan untuk sesuai keperluan dan menyatakan bahwa perkembangan sistem informasi dan komputer dapat digunakan diberbagai aspek kehidupan.

\section{METODE PENELITIAN}

Metode penelitian yang dilakukan adalah metode penelitian eksperimen, dengan tahapan penelitian seperti berikut:

\section{Pengumpulan Data}

Penelitian ini menggunakan data curah hujan, suhu dan kelembapan dari tahun $2010-2015$

Tabel Sample Data untuk curah hujan untuk 1 tahun Periode 2010

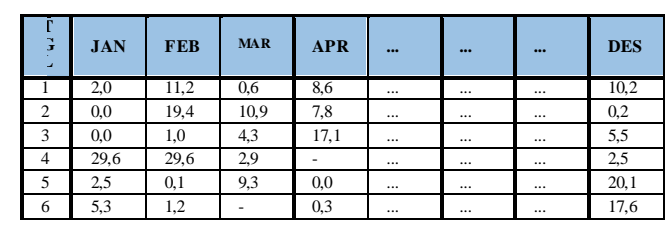

Tabel Sample Data untuk Suhu Udara untuk 1 tahun Periode 2010

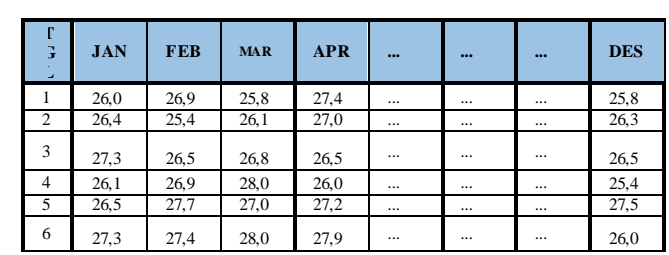

Tabel Sample Data untuk Kelembapan untuk 1 tahun Periode 2010

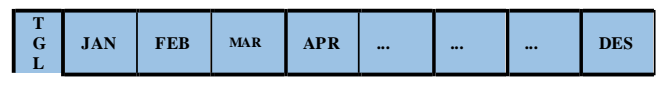

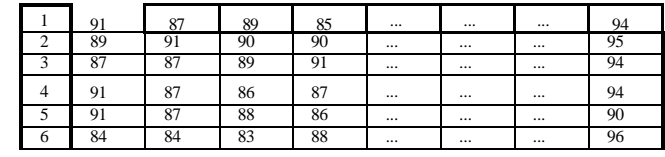

2. Pengolahan Data Awal

Tahapan ini dilakukan untuk mempersiapkan data yang telah di peroleh dari tahap pengumpulan data. Setelah itu melakukan proses preprocessing yaitu penskalaan nilainilai yang disesuaikan dengan beberapa kriteria dan parameter. Kriteria prediksi yaitu curah hujan, suhu dan kelembaban masing-masing kriteria memiliki parameter yang mencerminkan keanggotaan dalam himpunan fuzzy. Fungsi Keanggotaan yang di peroleh berdasarkan pada software pendukung dalam pengujian ini.

\section{Metode Yang Diusulkan}

Metode yang diusulkan dalam penelitian ini adalah menerapkan metode ANFIS (Adaptive Neuro-Fuzzy Inference System) untuk memprediksi curah hujan dengan menganalisa membership function dalam proses penarikan kesimpulan.

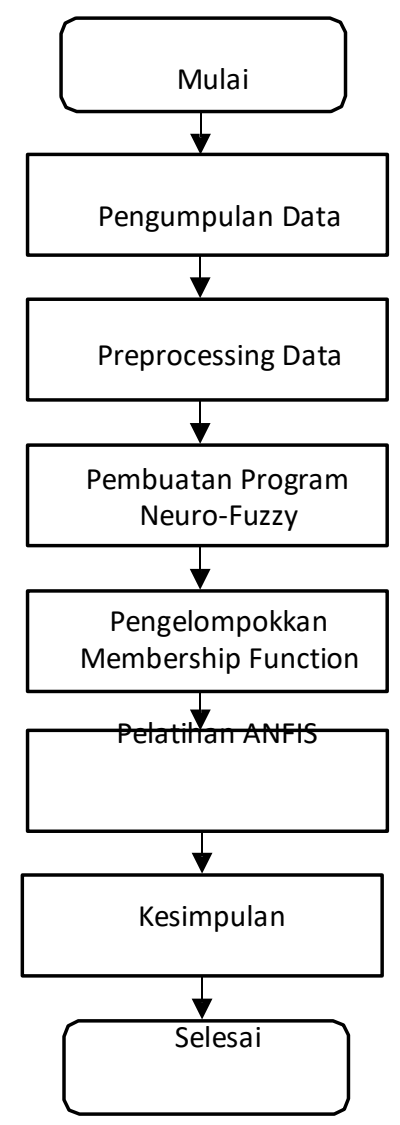




\section{Lokasi Penelitian}

Lokasi untuk penelitian ini adalah di BMKG Stasiun Meteorologi Stagen Kotabaru Kalimantan Selatan sebagai tempat untuk pengambilan data.

\section{ANALISIS HASIL DAN PEMBAHASAN}

Pada penelitian ini menggunakan 1827 data untuk setiap variabel input yang dipakai sebagai pembangun logika yaitu dari tahun 2010 sampai tahun 2014. Data 2010-2014 akan dipergunakan sebagai data training dan validasi data 2015 akan digunakan sebagai data checking. Evaluasi dilakukan dengan mengamati hasil prediksi dibandingkan dengan data awal yang diolah.

\section{Tabel Data Preprocessing Sample periode 1 tahun}

\begin{tabular}{|c|c|c|}
\hline Suhu & Kelembaban & Hujan \\
\hline 27,2 & 78 & 4,5 \\
\hline 28 & 74 & 0 \\
\hline 25,9 & 85 & 22,7 \\
\hline 26,8 & 79 & 0 \\
\hline 27,3 & 84 & 1,5 \\
\hline 26,1 & 86 & 30 \\
\hline 26,4 & 88 & 32,5 \\
\hline 30 & 65 & 40,4 \\
\hline 27,5 & 82 & 0 \\
\hline 28,5 & 74 & 1,5 \\
\hline 26,9 & 87 & 19,5 \\
\hline 26,6 & 90 & 8,6 \\
\hline 26,5 & 90 & 37,5 \\
\hline$\ldots$ & $\ldots$ & $\ldots$ \\
\hline$\ldots$ & $\ldots$ & $\ldots$ \\
\hline$\ldots$ & $\ldots$ & $\ldots$ \\
\hline$\ldots$ & $\ldots$ & $\ldots$ \\
\hline 4 & 25,6 & 88 \\
\hline
\end{tabular}

Pada metode fuzzy FIS dengan fuzzy sugeno ini, pertama kali adalah menentukan variabel input dan variabel output dimana ada 2 variabel yang digunakan pada penelitian ini yaitu Unsur cuaca yang digunakan sebagai masukan adalah suhu dan kelembaban, kedua variabel ini digunakan sebagai masukan karena variabel-variabel ini penyebab utama terjadinya hujan, dan data keluaran adalah curah hujan seperti pada tabel berikut ini :

Tabel Variabel Curah Hujan

\begin{tabular}{|c|c|c|c|c|}
\hline \multirow{2}{*}{ Funges } & Naima & Semesta & \multirow[b]{2}{*}{ Satuen } & \multirow[b]{2}{*}{ Keterangan } \\
\hline & Yariabel & Pembiraraan & & \\
\hline \multirow[t]{2}{*}{ inpul } & sulm & $18,0-30,2$ & Celeias & Soduiudars \\
\hline & Keltrnitulun & $60-100$ & Penes: & 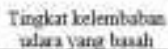 \\
\hline Outpat & Cuahl Hujan & $0-120$ & $\operatorname{man}$ & 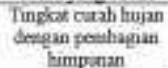 \\
\hline
\end{tabular}

Ada 2 anggota himpunan dalam parameter curah hujan yang telah ditentukan anggota himpunannya terdiri pada tabel

\begin{tabular}{|c|c|c|}
\hline Nama Variabel & \multicolumn{2}{|c|}{ Himpunan Fuzzy } \\
\hline \multicolumn{3}{|l|}{ Input } \\
\hline \multirow{3}{*}{ Suhu } & Rendah & $18,0-21,9$ Celcius \\
\hline & Sedang & $22,0-26,9$ Celcius \\
\hline & Tinggi & $27,0-30,9$ Celcius \\
\hline \multirow{3}{*}{ Kelembaban } & Rendah & $60-75 \%$ \\
\hline & Sedang & $76-85 \%$ \\
\hline & Tinggi & $85-100 \%$ \\
\hline \multicolumn{3}{|l|}{ Output } \\
\hline \multirow{3}{*}{ Curah Hujan } & Ringan & $0-40 \mathrm{~mm}$ \\
\hline & Sedang & $41-80 \mathrm{~mm}$ \\
\hline & Lebat & $81-120 \mathrm{~mm}$ \\
\hline
\end{tabular}

Himpunan keanggotaan fuzzy tersebut diimplementasikan menggunakan fuzzy sugeno dengan tools matlab R2010a dengan hasil sebagai berikut :

a. Suhu

Himpunan keanggotaan fuzzy pada variabel suhu ada 3 yakni rendah, sedang dan tinggi. Dengan fungsi keanggotaan sebagai berikut : 


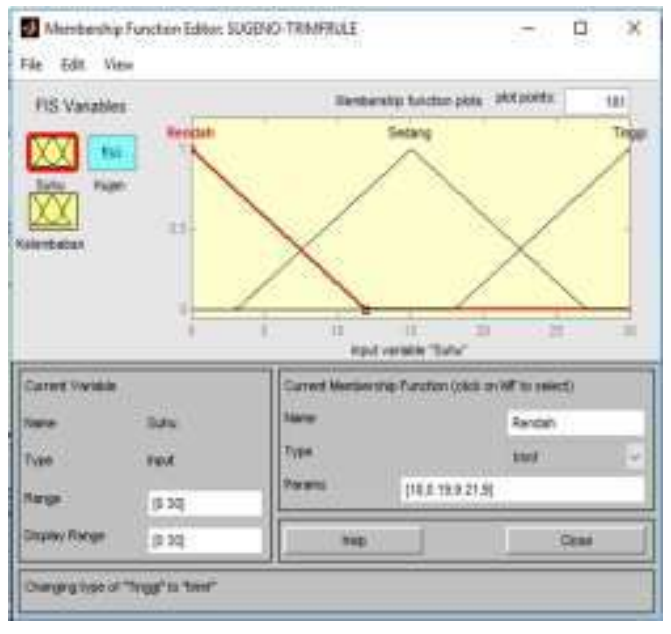

Gambar Himpunan Fuzzy Suhu dengan MF Trimf

b. Kelembaban

Himpunan keanggotaan fuzzy pada variabel kelembaban ada 3 yakni rendah, sedang dan tinggi. Dengan fungsi keanggotaan sebagai berikut

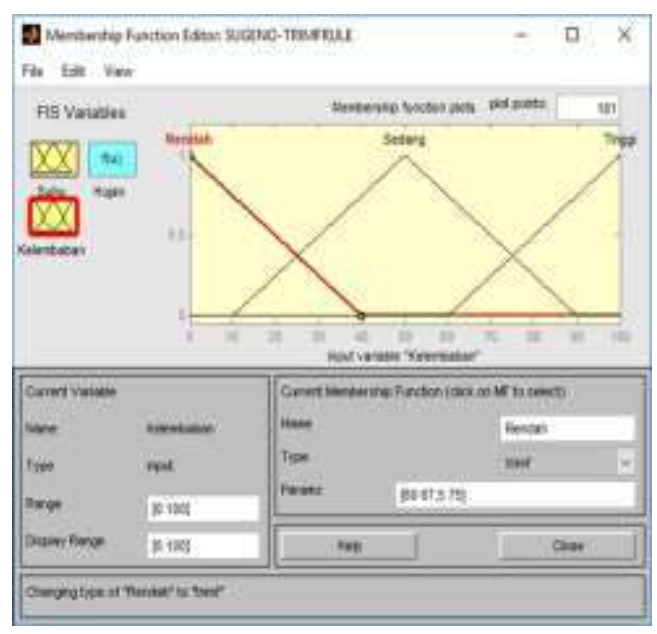

Gambar Himpunan Fuzzy Lembab dengan MF Trimf

Dalam implementasi ANFIS ada beberapa operator yang digunakan untuk pengujian ini. Ada 9 aturan yang dijabarkan seperti dibawah ini

\section{Aturan Ke-1}

IF suhu RENDAH dengan kelembaban RENDAH maka curah hujan termasuk hujan RINGAN

Aturan Ke-2

IF suhu RENDAH dengan kelembaban SEDANG maka curah hujan termasuk hujan RINGAN

\section{Aturan Ke-3}

IF suhu RENDAH dengan kelembaban TINGGI maka curah hujan termasuk hujan SEDANG

\section{Aturan Ke-4}

IF suhu SEDANG dengan kelembaban RENDAH maka curah hujan termasuk hujan RENDAH

\section{Aturan Ke-5}

IF suhu SEDANG dengan kelembaban SEDANG maka curah hujan termasuk hujan SEDANG

Aturan Ke-6

IF suhu SEDANG dengan kelembaban TINGGI maka curah hujan termasuk hujan SEDANG

Aturan Ke-7

IF suhu TINGGI dengan kelembaban RENDAH maka curah hujan termasuk hujan SEDANG

Aturan Ke-8

IF suhu TINGGI dengan kelembaban RENDAH maka curah hujan termasuk hujan LEBAT

Aturan Ke-9

IF suhu TINGGI dengan kelembaban RENDAH maka curah hujan termasuk hujan

LEBAT 


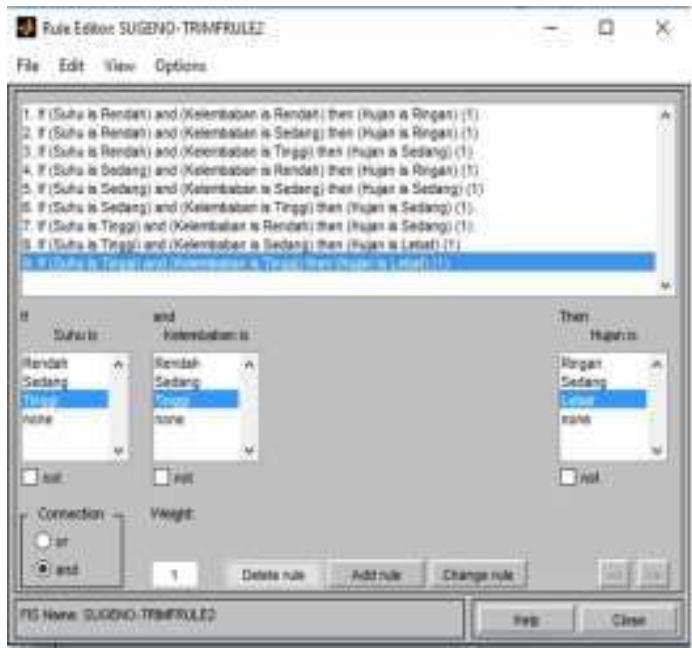

Gambar Rule Fuzzy Curah Hujan

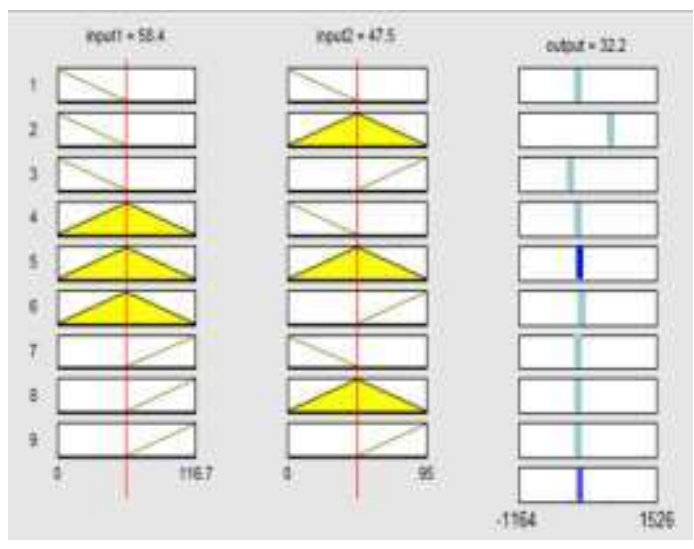

Gambar Hasil rule dengan Kelembaban, Suhu dan Hujan

Keterangan :

Input 1 : Lembab

Input 2 : Suhu

Output : Hujan

Dari gambar diatas menjelaskan hasil dengan memisalkan data lembab 58,4 dan suhu 47,5, maka curah hujan yang didapat adalah 32,2, dimana hasil gambar ini menggunakan membership function Trimf dengan nilai RMSE 0,73436.

Hasil Arsitektur ANFIS yang didapat pada gambar dibawah ini :

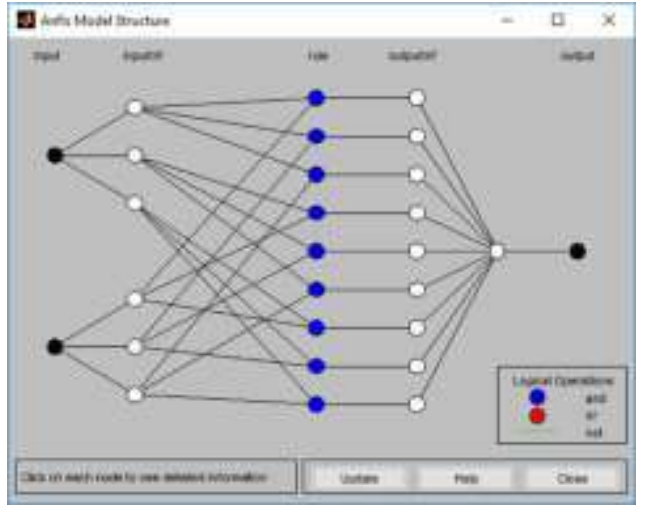

Tabel Evaluasi Hasil

\begin{tabular}{|c|c|c|c|c|c|c|c|}
\hline \multirow{2}{*}{ No } & \multirow{2}{*}{ Pengujian } & \multirow{2}{*}{$\begin{array}{l}\text { Error } \\
\text { Toleran } \\
\text { ce }\end{array}$} & \multirow{2}{*}{$\begin{array}{l}\text { Epo } \\
\text { ch }\end{array}$} & \multicolumn{4}{|c|}{ RMSE } \\
\hline & & & & $\begin{array}{l}\text { Trap } \\
\mathrm{mf}\end{array}$ & $\begin{array}{l}\text { Trim } \\
\mathrm{f}\end{array}$ & $\begin{array}{l}\text { Gaus } \\
\text { smf }\end{array}$ & Bell \\
\hline 1 & P1 & 0,01 & 10 & 5,19 & $\begin{array}{l}4,97 \\
68\end{array}$ & $\begin{array}{l}5,13 \\
89\end{array}$ & $\begin{array}{l}5,14 \\
46\end{array}$ \\
\hline 3 & P3 & 0,01 & 90 & $\begin{array}{l}3,93 \\
93\end{array}$ & $\begin{array}{l}3,59 \\
02\end{array}$ & $\begin{array}{l}3,85 \\
84\end{array}$ & $\begin{array}{l}3,87 \\
74\end{array}$ \\
\hline 6 & P6 & 0,3 & 35 & $\begin{array}{l}2,92 \\
66\end{array}$ & $\begin{array}{l}2,92 \\
2\end{array}$ & $\begin{array}{l}2,92 \\
63 \\
\end{array}$ & $\begin{array}{l}2,92 \\
61\end{array}$ \\
\hline 10 & P10 & 0,4 & 50 & $\begin{array}{l}0,75 \\
793\end{array}$ & $\begin{array}{l}0,76 \\
453\end{array}$ & $\begin{array}{l}0,75 \\
396\end{array}$ & $\begin{array}{l}0,75 \\
193\end{array}$ \\
\hline 12 & P12 & 0,4 & 50 & $\begin{array}{l}0,97 \\
001\end{array}$ & $\begin{array}{l}0,96 \\
724\end{array}$ & $\begin{array}{l}0,96 \\
91\end{array}$ & $\begin{array}{l}0,96 \\
927\end{array}$ \\
\hline 16 & P16 & 0,5 & 80 & $\begin{array}{l}0,87 \\
37\end{array}$ & $\begin{array}{l}0,86 \\
419\end{array}$ & $\begin{array}{l}0,86 \\
681\end{array}$ & $\begin{array}{l}0,86 \\
536\end{array}$ \\
\hline 17 & P17 & 0,4 & 40 & 5,19 & $\begin{array}{l}5,54 \\
93\end{array}$ & $\begin{array}{l}5,50 \\
24\end{array}$ & $\begin{array}{l}5,50 \\
24\end{array}$ \\
\hline 18 & P18 & 0 & 70 & $\begin{array}{l}0,87 \\
37\end{array}$ & $\begin{array}{l}0,86 \\
419\end{array}$ & $\begin{array}{l}0,86 \\
681\end{array}$ & $\begin{array}{l}0,86 \\
536\end{array}$ \\
\hline 19 & P19 & 0,6 & 20 & $\begin{array}{l}0,97 \\
001\end{array}$ & $\begin{array}{l}0,96 \\
724\end{array}$ & $\begin{array}{l}0,96 \\
91\end{array}$ & $\begin{array}{l}0,96 \\
927\end{array}$ \\
\hline 20 & P20 & 0 & 100 & $\begin{array}{l}0,74 \\
387\end{array}$ & $\begin{array}{l}0,73 \\
436\end{array}$ & $\begin{array}{l}0,74 \\
1\end{array}$ & $\begin{array}{l}0,73 \\
8\end{array}$ \\
\hline 23 & P23 & 0,1 & 200 & $\begin{array}{l}4,56 \\
72\end{array}$ & $\begin{array}{l}4,57 \\
95\end{array}$ & $\begin{array}{l}4,59 \\
11\end{array}$ & $\begin{array}{l}4,58 \\
52\end{array}$ \\
\hline
\end{tabular}

Dari Evaluasi hasil analisa, maka dapat disumpulkan bahwa pengujian ke P20 yang memiliki nilai RMSE paling kecil untuk metode ANFIS dengan membership funtion Trimf (Segitiga) yaitu 0,73436 dengan error tolerance 0 dan epoch 100. Sedangkan dari pengujian didapatkan hasil bahwa diantara pengujian yang P20 yang menghasilkan nilai RMSE terkecil dengan semua membership function yang ada yaitu trapesium, segitiga, gaussian, dan bell.

Pada penelitian ini menggunakan 1825 data untuk setiap variabel input yang dipakai sebagai pembangun logika yaitu dari tahun 2010 sampai tahun 2014. Data yang telah terkumpul dan terbagi dalam klasifikasi, dipakai sebagai membership function dalam penyusunan program. Setelah itu dilakukan pengujian dengan data input dari bulan Januari 2015 hingga Desember 2015, yaitu sebanyak 365 data. Dan pengujiaan ini 
menggunakan beberapa membership function seperti Representasi Trapesium, Representasi Kurva Segitiga, dan Representasi Gaussian.untuk mencari hasil yang lebih baik. Data hasil penelitian menyimpulkan bahwa ANFIS memprediksi tingkat curah hujan yang akurat.

Pada gambar hasil rule menjelaskan bahwa dengan kelembaban $58,4 \%$ dan suhu 47,5 celcius maka curah hujan 32,2 $\mathrm{mm}$ yang berarti akan terjadi hujan dengan intensitas hujan rendah dengan hasil akurasi / RMSE 0,73436 pada fungsi keanggotaan segitiga pada fuzzy sugeno.

\section{PENUTUP}

\section{Kesimpulan}

Berdasarkan hasil penelitian dan pengukuran, penerapan ANFIS ini memiliki nilai lebih dalam proses menganalisis akurasi / prediksi besaran curah hujan dengan pengujian dalam berbagai proses yang sudah di jelaskan di bab sebelumnya dengan membership function yang berbeda untuk mencari yang mana diantara semua fungsi keanggotaan membership function / fungsi keanggotaan seperti membership function trapmf (trapesium), membership function trimf (segitiga), membership function gaussmf (gaussian), dan membership function bellmf (bell) yang memiliki nilai akurasi / prediksi yang tinggi. Dengan menggunakan data pendukung seperti kelembaban 58,4\% dan suhu 47,5 celcius maka curah hujan $32,2 \mathrm{~mm}$ yang berarti akan terjadi hujan dengan intensitas hujan rendah dengan hasil akurasi / RMSE 0,73436 pada fungsi keanggotaan segitiga, yang berarti dibandingkan semua fungsi keanggotaan I membership function yang ada, membership function segitiga lah yang memiliki nilai error yang kecil yang berarti bahwa hasil prediksinya benar sehingga menjadi prakiraan curah hujan yang lebih baik dibandingkan dengan beberapa fungsi keanggotaan lain dengan data pendukung yang berbeda-beda.

Dengan demikian, adanya penerapan ANFIS dapat membantu memberikan solusi kepada petugas ataupun instansi terkait, serta mampu menjadi alat prediksi curah hujan yang dapat digunakan oleh BMKG Provinsi Kalimantan Selatan, khususnya Stasiun Meteorologi Stagen Kotabaru Kalimantan Selatan.

\section{DAFTAR PUSTAKA}

[1] BMKG, Prakiraan Musim Hujan 2010/2011 di Indonesia, 2010.

[2] Kusumadewi, S., S. Hartati, 2006,Neuro Fuzzy Integrasi Sistem Fuzzy dan Jaringan Syaraf, Grahallmu,Yogyakarta

[3] Fithriah Musadat, Zahir Zainuddin, and Merna Baharuddin "Algorithm Implementation Of Rain Precipitation Forecasting In Early Flood Disaster Detection System, 2012

[4] Suhartono, Ria Faulina, Dwi Ayu Lusia, Bambang W. Otok, Sutikno, Heri Kuswanto "Ensemble Method based on ANFIS-ARIMA for Rainfall Prediction"

[5] Deni Septiadi, Aplikasi Soft Computing Pada Prediksi Curah Hujan Di Kalimantan, 2008

[6] Anif Hanifa Setyaningrum, Praditya Megananda Swarinata, "Weather Prediction Application Based on ANFIS (Adaptive Neural Fuzzy Inference System) Method In West Jakarta Region", 2014

[7] Yusmen, Dedi. "Pengaruh ENSO terhadap pola curah, hujan di Wilayah DAS Brantas Selatan-Jawa Timur, Jurusan Geofisika dan Meteorologi, FMIPA ITB 1998. 
[8] Siang Jong Jek, Jaringan Syaraf Tiruan dan Pemrogramannya, 2nd ed. Yogyakarta: Penerbit Andi, 2009

[10] Kadarsah and Ahmad Sasmita, "Standardisasi Metadata Klimatologi Dalam Penelitian Perubahan Iklim Di Indonesia," in Prosiding PPI Standardisasi 2010, Banjarmasin, 2010, pp. 1 18.

[11] Ifan Wiranto, Wahab Musa, Wrastawa Ridwan "Prediksi Curah Hujan Tahunan Menggunakan ANFIS Dengan Pengelompokkan Data"

[12] Ardian Candra Pratama, Ir. Syamsul A,M.T, Dr. Ir. Aulia S.A, M.T [16] "Perancangan Model Adaptive Neuro Fuzzy Inference System Untuk Memprediksi Cuaca Maritim", 2010 